\title{
A high mountain lizard from Peru: The world's highest-altitude reptile
}

\author{
José Cerdeñaํ, Jackie Farfán, Aarón J. Quiroz \\ 1 Universidad Nacional de San Agustín de Arequipa, Museo de Historia Natural, Av. Alcides Carrion s/n, Arequipa, Peru \\ http://zoobank.org/F5A100CA-B60F-4922-80D7-E2D7634C65FE \\ Corresponding author: Jose Cerdeña (cerdenajoseal@yahoo.es)
}

Academic editor: Johannes Foufopoulos • Received 27 November 2020 Accepted 4February 2021 Published 15 February 2021

\begin{abstract}
Life at high altitudes is particularly challenging for ectothermic animals like reptiles and involves the evolution of specialised adaptations to deal with low temperatures, hypoxia and intense UV radiation. As a result, only very few reptile taxa are able to survive above 5,000 m elevation and herpetological observations from these altitudes are exceedingly rare. We report here an exceptional observation of a lizard population (Liolaemus aff. tacnae; Reptilia, Squamata) from the high Andes of Peru. During an ascent of Chachani mountain $\left(6,054 \mathrm{~m}, 16^{\circ} 11^{\prime} \mathrm{S}, 71^{\circ} 32^{\prime} \mathrm{W}\right)$, we observed and documented photographically this species living between 5,000 and 5,400 $\mathrm{m}$ above sea level. Following a review of literature, we show that this is the highest known record of a reptile species.
\end{abstract}

\section{Key Words}

Liolaemus, alticolor-bibronii group, L. tacnae, Chachani, Arequipa

\section{Introduction}

Adaptation to high elevation life in reptiles implicates different specialised anatomical and physiological strategies (Huey 1982; He et al. 2013; Reguera et al. 2014; Kouyoumdjian et al. 2019), which scientists are recently beginning to understand at the genetic level (Yang et al. 2014; Yang et al. 2015; Li et al. 2018). Factors identified as important in reptiles for allowing survival at the upper altitudinal limits relate to food availability and capacities for tolerating hypoxia and low temperatures (Navas 2002; Lu et al. 2018; Gangloff et al. 2019). Prior to this publication, the highest known altitude records for reptiles came from species in two lizard genera, Phrynocephalus (up to $5,300 \mathrm{~m}$ ) from the Tibetan plateau and Liolaemus (up to 5,176 m) from the Andes (Zhao et al. 1999; Aparicio and Ocampo 2010; Li et al. 2017).

The South American genus Liolaemus constitutes one of the most diverse genera of reptiles known on Earth, with more than 270 species described to date (Abdala et al. 2020; Huamaní-Valderrama et al. 2020); it is distributed from the Central Andes in Peru to Patagonia in Argentina (Pincheira-Donoso et al. 2008; Aguilar et al. 2013; Abdala et al. 2020). This includes the coastal regions of southern Peru and northern Chile (Valladares et al. 2004; Villegas-Paredes et al. 2020), as well as southern Brazil (Verrastro et al. 2003) and demonstrates a broad adaptive radiation of the genus in the region (Abdala et al. 2020). In Peru, 28 species in the genus Liolaemus have been described to date (Chaparro et al. 2020; Huamaní-Valderrama et al. 2020; Arapa-Aquino et al. 2021), although recent phylogenetic analyses have shown that this number is likely an underestimate, given the existence of several undescribed lineages or "candidate species" (Aguilar et al. 2017, 2018; Abdala et al. 2020; Huamaní-Valderrama et al. 2020).

\section{Observations}

On 18 October 2020, we ascended the summit of the Chachani mountain $(6,054 \mathrm{~m})$, located $20 \mathrm{~km}$ north 
of Arequipa in south-western Peru. At approximately 09:00 hrs (local time) and at an elevation of 5,000 $\mathrm{m}$, we observed from a distance of approximately five metres two small lizards moving and then hiding between large rocks, making further observations difficult. Later, during the same day, between 10:00 and 12:00 hrs (local time), a total of ten lizards of the same characteristics were observed between 5,000 and 5,400 $\mathrm{m}$ of elevation (Fig. 1A), where they were moving amongst the rocks. One individual was photographed at $5,400 \mathrm{~m}$ elevation (Fig. 1B), with coordinates $16^{\circ} 10^{\prime} 57^{\prime \prime S}, 71^{\circ} 32^{\prime} 02^{\prime \prime} \mathrm{W}$ (Fig. 2). The habitat at the site is characterised by large rocks on the mountain slopes and the almost complete absence of vegetation (Fig. 1A), with only small herbaceous plants growing near the protected underside of rocks. The lizards were exclusively saxicolous, being observed moving only on rocky substrate.

Based on the pattern, colouration and size (approx. $11 \mathrm{~cm}$ total length) of the observed animals, we consider them to belong to the alticolor-bibronii group of the genus Liolaemus. We provisionally assign this population to Liolaemus aff. tacnae, because of its similarity to the L. tacnae which inhabits Chiguata (4,000 m elevation), approx. $30 \mathrm{~km} \mathrm{SE}$ of Chachani mountain (Aguilar et al. 2013). However, a more detailed analysis is needed, including use of morphological and/or molecular evidence, to determine with more confidence the taxonomic status of this high mountain population.
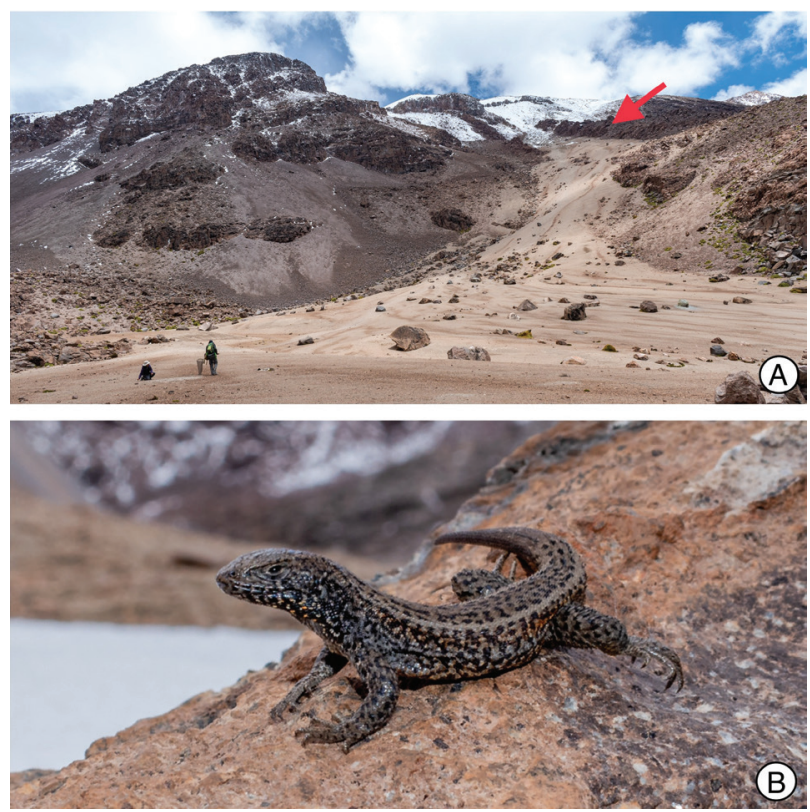

Figure 1. The highest-altitude record for a reptile. A. View of the new record location, on the route of ascent from 5,000 $\mathrm{m}$ to the summit of Chachani mountain, south-western Peru. B. Adult specimen of $L$. aff. tacnae photographed at 5,400 m altitude (place of photography indicated with a red arrow in Fig. 1A).

The present observations represent the highest documented record for the genus Liolaemus, surpassing by more than 200 m elevation the previous record holders:

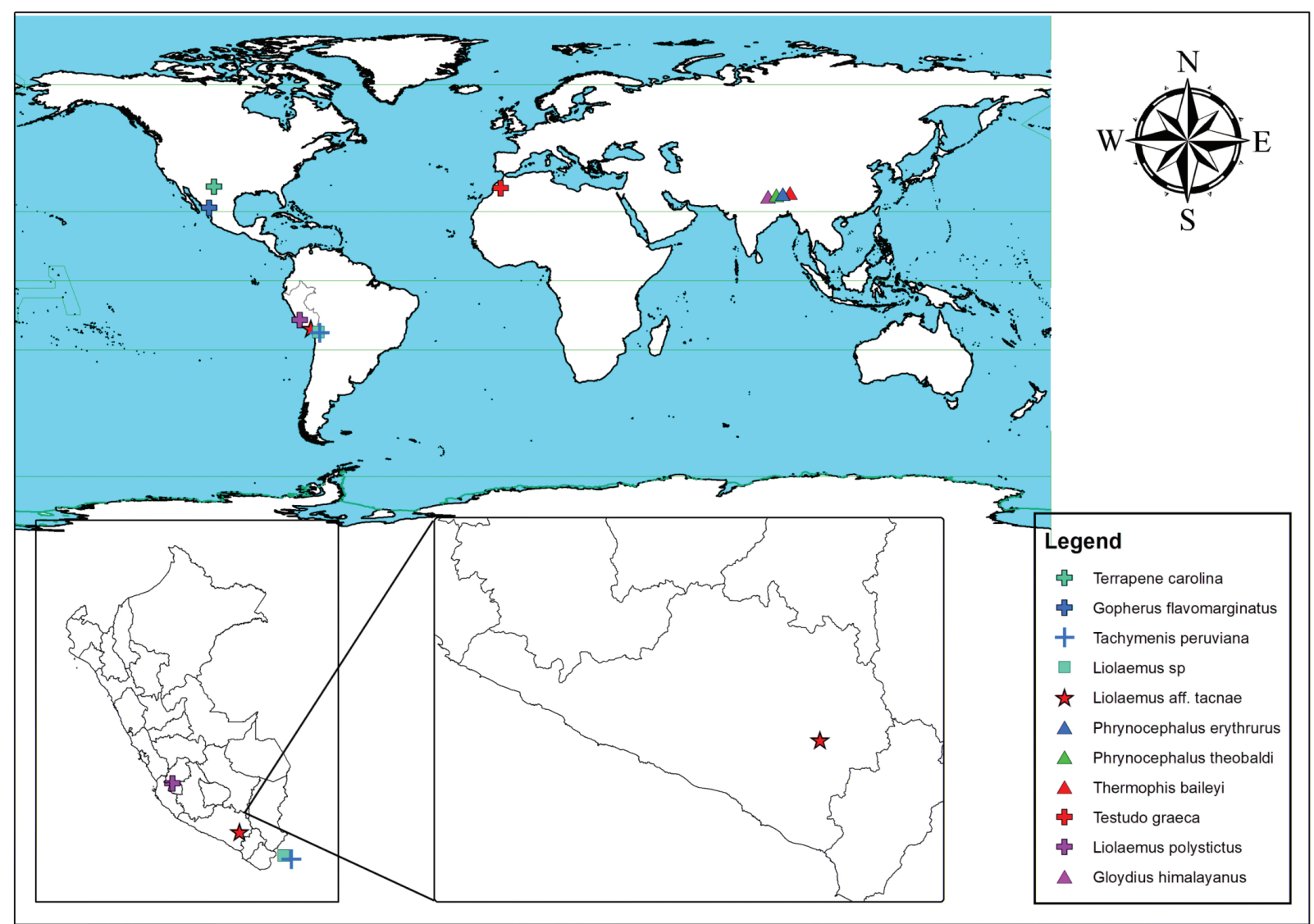

Figure 2. Map of the locations of highest altitude records of reptiles listed in Table 1. 
Table 1. The world's highest altitude records for three major groups of terrestrial reptiles.

\begin{tabular}{|c|c|c|c|c|c|}
\hline Group & Family & Specie & Altitude (m) & Region & Reference \\
\hline \multirow[t]{5}{*}{ Lizards } & Liolaemidae & Liolaemus aff. tacnae & $5000-5400$ & South America & Present study \\
\hline & Agamidae & Phrynocephalus erythrurus Zugmayer, 1909 & $4500-5300$ & Asia & Zhao et al. 1999; Li et al. 2017 \\
\hline & Liolaemidae & Liolaemus sp. & $5060-5176$ & South America & Aparicio and Ocampo 2010 \\
\hline & Agamidae & Phrynocephalus theobaldi Blyth, 1863 & $3600-5100$ & Asia & Zhao et al. 1999; Jin et al. 2017 \\
\hline & Liolaemidae & Liolaemus polystictus Laurent 1992 & $4043-5016$ & South America & Olivera and Aguilar 2020 \\
\hline \multirow[t]{3}{*}{ Snakes } & Colubridae & Thermophis baileyi Wall, 1907 & $3600-4900$ & Asia & Dorge et al. 2007 \\
\hline & Viperidae & Gloydius himalayanus (Gunther, 1864) & $1500-4850$ & Asia & Whitaker and Captain 2004; Saikia et al. 2007 \\
\hline & Dipsadidae & Tachymenis peruviana Wiegmann, 1834 & $1800-4600$ & South America & Miranda et al. 2015; Gallardo et al. 2019 \\
\hline \multirow[t]{3}{*}{ Turtles } & Testudinidae & Testudo graeca Linnaeus, 1758 & $0-2090$ & North Africa & Anadón et al. 2012 \\
\hline & Testudinidae & Gopherus flavomarginatus Legler, 1959 & $1000-2000$ & North America & Becerra-López et al. 2017 \\
\hline & Emydidae & Terrapene carolina Linnaeus, 1758 & $300-1875$ & North America & Diggins et al. 2016 \\
\hline
\end{tabular}

two Bolivian populations of Liolaemus reported between 5,060 and 5,176 m (Aparicio and Ocampo 2010). This population of $L$. aff. tacnae represents the reptile species that lives at the highest altitude on Earth (Table 1), exceeding by $100 \mathrm{~m}$ the record documented for the Asian species Phrynocephalus erythrurus, which inhabits the Tibetan plateau between 4,500 and 5,300 metres elevation (Zhao et al. 1999; Li et al. 2017).

The ongoing global warming trend has probably facilitated the survival of $L$. aff. tacnae at this record high site. The genus Liolaemus is well-adapted to a broad range of environments (Pincheira-Donoso et al. 2015) and climate change is expected to favour the expansion of species at their upper altitudinal limits (e.g. Wilson et al. 2005, but also see Parmesan 2006 for exceptions). This is particularly true for ectothermic animals, such as the lizards, whose vital functions are known to be directly dependent on ambient temperatures (Sinervo et al. 2018).

\section{Conclusions}

We hope that this report will encourage future research into the physiological mechanisms that allow these animals to live at such extremely high elevations through adaptations to low temperatures and low oxygen availability (e.g. Bennett and Ruben 1975; Lu et al. 2015; Cordero et al. 2017; Gangloff et al. 2019).

\section{Acknowledgements}

The authors are very grateful to Ivan Jimenez and Ander Tejada for their support in the ascent of the Chachani mountain. To Mr. Libio Roy Santa Cruz of the Herpetology Area of the Natural History Museum of Universidad Nacional de San Agustin de Arequipa (UNSA) for facilitating access to the collections under their care. We also thank Juan Carlos Chaparro for assistance in the preparation of the map. We acknowledge the Subject Editor, Johannes Foufopoulos, for his reading and corrections. Our thanks also go to the reviewers of the document for their valuable comments.

\section{References}

Abdala CS, Quinteros AS, Semhan RV, Bulacios-Arroyo AL, Schulte J, Paz MM, Ruiz-Monachesi MR, Laspiur A, Aguilar-Kirigin AJ, Gutiérrez Poblete R, Valladares Faundez P, Valdés J, Portelli S, Santa-Cruz R, Aparacio J, García N, Langstroth R (2020) Unravelling interspecific relationships among highland lizards: first phylogenetic hypothesis using total evidence of the Liolaemus montanus group (Iguania: Liolaemidae). Zoological Journal of the Linnean Society 189(1): 349-377. https://doi.org/10.1093/zoolinnean/zlz114

Aguilar C, Wood Jr PL, Belk M, Duff MH, Sites Jr JW (2017) Different roads lead to Rome: Integrative taxonomic approaches lead to the discovery of two new lizard lineages in the Liolaemus montanus group (Squamata: Liolaemidae). Biological Journal of the Linnean Society 120: 448-467. https://doi.org/10.1111/bij.12890

Aguilar C, Avila LJ, De la Riva I, Johnson L, Morando M, Troncoso-Palacios J, Wood Jr PL, Sites Jr JW (2018) The shadow of the past: convergence of young and old South American desert lizards as measured by head shape traits. Ecology and Evolution 8: 11399-11409. https://doi.org/10.1002/ece3.4548

Aguilar C, Wood Jr PL, Cusi JC, Guzmán A, Huari F, Lundberg M, Mortensen E, Ramírez C, Robles D, Suárez J, Ticona, A, Vargas VJ, Venegas PJ, Sites Jr JW (2013) Integrative taxonomy and preliminary assessment of species limits in the Liolaemus walker complex (Squamata, Liolaemidae) with descriptions of three new species from Peru. ZooKeys 364: 47-91. https://doi.org/10.3897/zookeys.364.6109

Anadón JD, Giménez A, Graciá E, Pérez I, Rouag R, Larbes S, Kalboussi M, Fahd S, Znari M, El Mouden H, Slimani T, Jdeidi T (2012) Distribution of Testudo graeca in Western Mediterranean according to climatic factors. Amphibia-Reptilia 33: 285-296. https://doi. org/10.1163/156853812X643710

Aparicio J, Ocampo M (2010) Liolaemus grupo montanus Etheridge, 1995 (Iguania-Liolaemidae). Novedad zoogeográfica. Cuadernos de Herpetología 24(2): 133-135. http://ppct.caicyt.gov.ar/index.php/ cuadherpetol/article/view/996/906

Arapa-Aquino LP, Abdala CS, Huamaní-Valderrama L, Gutierrez RC, Cerdeña JA, Quiroz JA, Chaparro JC (2021) Una nueva especie de lagartija del género Liolaemus (Iguania: Liolaemidae) endémica de la Puna del sur de Perú. Cuadernos de Herpetología, 35 (Suppl. 1): 35-48. http://ppct.caicyt.gov.ar/index.php/cuadherpetol/article/ view/19508/45454575771299

Becerra-López JL, García-De la Peña C, Romero-Méndez U, Ramírez-Bautista A (2017) Plant cover effect on Bolson tortoise (Gopherus flavomarginatus Legler 1959, Testudinidae) burrow use. 
Nature Conservation 17: 57-69. https://doi.org/10.3897/natureconservation. 17.11582

Bennett AF, Ruben J (1975) High altitude adaptation and anaerobiosis in sceloporine lizards. Comparative Biochemistry and Physiology Part A: Physiology 50(1): 105-108. https://doi.org/10.1016/S0010406X(75)80209-X

Chaparro JC, Quiroz, AJ, Mamani L, Gutiérrez RC, Condori P, De la Riva I, Herrera-Juárez G, Cerdeña J, Arapa LP, Abdala CS (2020) An endemic new species of Andean lizard of the genus Liolaemus from southern Perú (Iguania: Liolaemidae) and its phylogenetic position. Amphibian \& Reptile Conservation 14(2): 47-63 (e238). http://amphibian-reptile-conservation.org/pdfs/Volume/Vol_14 no_2/ARC_14_2_[General_Section]_47-63_e238.pdf

Cordero GA, Andersson BA, Souchet J, Micheli G, Noble DWA, Gangloff EJ, Uller T, Aubret F (2017) Physiological plasticity in lizard embryos exposed to high-altitude hypoxia. Journal of Experimental Zoology Part A: Ecological and Integrative Physiology 327(7): 423-432. https://doi.org/10.1002/jez.2115

Diggins CA, Higdon SD, Ford WM (2016) High-elevation record for eastern box turtle in the southern Appalachians. Herpetological Review 47(3): e454. https://ssarherps.org/herpetological-review-pdfs/

Dorge T, Hofmann S, Wangdwei M0, Duoje L, Solhoy T, Miehe G (2007) The ecological specialist, Thermophis baileyi (Wall, 1907) - new records, distribution and biogeographic conclusions. The Herpetological Bulletin 101: 8-12. https://www.thebhs.org/publications/the-herpetological-bulletin/issue-number-101-autumn2007/3046-hb101-03?format=html

Gallardo GA, Nenda SJ, Scrocchi MGJ (2019) Tachymenis peruviana Wiegmann, 1834 (Serpentes, Dipsadidae) in Argentina: geographic distribution and a new province record. Check List 15(1): 7-12. https://doi.org/10.15560/15.1.7

Gangloff EJ, Sorlin M, Cordero GA, Souchet J, Aubret F (2019) Lizards at the Peak: Physiological plasticity does not maintain performance in lizards transplanted to high altitude. Physiological and Biochemical Zoology 92(2): 189-200. https://doi.org/10.1086/701793

He J, Xiu M, Tang X, Yue F, Wang N, Yang S, Chen Q (2013) The different mechanisms of hypoxic acclimatization and adaptation in lizard Phrynocephalus vlangalii living on Qinghai-Tibet Plateau. Journal of Experimental Zoology Part A: Ecological Genetics and Physiology 319(3): 117-123. https://doi.org/10.1002/jez.1776

Huamaní-Valderrama L, Quiroz AJ, Gutiérrez RC, Aguilar-Kirigin A, Huanca-Mamani W, Valladares-Faúndez P, Cerdeña J, Chaparro JC, Santa Cruz R, Abdala CS (2020) Some color in the desert: description of a new species of Liolaemus (Iguania: Liolaemidae) from southern Peru, and its conservation status. Amphibian \& Reptile Conservation 14(3): 1-30(e250). http://amphibian-reptile-conservation.org/pdfs/Volume/Vol_14_no_3/ARC_14_3_[Taxonomy_Section]_1-30_e250.pdf

Huey RB (1982) Temperature, physiology, and ecology of reptiles. In: Gans C, Pough FH (Eds) Biology of the Reptilia. Academic Press, New York, 25-91.

Jin Y, Liu N, Brown R (2017) The geography and timing of genetic divergence in the lizard Phrynocephalus theobaldi on the Qinghai-Tibetan plateau. Scientific Reports 7: e2281. https://doi.org/10.1038/ s41598-017-02674-4

Kouyoumdjian L, Gangloff EJ, Souchet J, Cordero GA, Dupoué A, Aubret F (2019) Transplanting gravid lizards to high elevation alters maternal and embryonic oxygen physiology, but not reproductive success or hatchling phenotype. Journal of Experimental Biology 222: jeb206839. https://doi.org/10.1242/jeb.206839

Li XT, Wang Y, Lu SS, Li M, Men SK, Bai YC, Tang XL, Chen Q (2017) The cold hardiness of Phrynocephalus erythrurus, the lizard living at highest altitude in the world. CryoLetters 38(3): 216-227. http://www.cryoletters.org/Abstracts/vol_38_3_2017.htm\#216

Li, JT, Gao YD, Xie L, Deng C, Shi P, Guan ML, Huang S, Ren JL, Wu DD, Ding L, Huang ZY, Nie H, Humphreys DP, Hillis DM, Wang WZ, Zhang YP (2018) Comparative genomic investigation of high-elevation adaptation in ectothermic snakes. Proceedings of the National Academy of Sciences of the United States of America 115: 8406-8411. https://doi.org/10.1073/pnas.1805348115

Lu S, Xin Y, Tang S, Yue F, Wang H, Bai Y, Niu Y, Chen Q (2015) Differences in hematological traits between high- and low-altitude lizards (genus Phrynocephalus). PLoS ONE 10: e0125751. https:// doi.org/10.1371/journal.pone.0125751

Lu HL, Xu CX, Zeng ZG, Du WG (2018) Environmental causes of between-population difference in growth rate of a high-altitude lizard. BMC Ecology 18: e37. https://doi.org/10.1186/s12898-018-0194-8

Miranda B, Jimenez RO, Paredes M (2015) Distribución y notas de historia natural de Tachymenis peruviana (Wiegmann, 1835) (Dipsadidae: Tachymenini) en Bolivia. Libro de Resumenes XVI Congreso Argentino de Herpetologia, San Miguel de Tucuman, Argentina, $306 \mathrm{pp}$.

Navas CA (2002) Herpetological diversity along Andean elevational gradients: links with physiological ecology and evolutionary physiology. Comparative Biochemistry and Physiology-Part A: Molecular \& Integrative Physiology 133: 469-485. https://doi.org/10.1016/ S1095-6433(02)00207-6

Olivera DA, Aguilar CA (2020) Dieta de la lagartija neotropical Liolaemus polystictus (Squamata: Liolaemidae) de los andes centrales, Huancavelica, Perú. Revista peruana de biología 27(3): 339-348. https://doi.org/10.15381/rpb.v27i3.18680

Parmesan C (2006) Ecological and evolutionary responses to recent climate change. Annual Review of Ecology, Evolution, and Systematics 37: 637-669. https://doi.org/10.1146/annurev.ecolsys.37.091305.110100

Pincheira-Donoso D, Scolorano JA, Sura P (2008) A monographic catalogue on the systematics and phylogeny of the South American iguanian lizard family Liolaemidae (Squamata, Iguania). Zootaxa 1800: 3-85. https://doi.org/10.11646/zootaxa.1800.1.1

Pincheira-Donoso D, Harvey LP, Ruta M (2015) What defines an adaptive radiation? Macroevolutionary diversification dynamics of an exceptionally species-rich continental lizard radiation. BMC Evolutionary Biology 15(1): e153. https://doi.org/10.1186/s12862-015-0435-9

Reguera S, Zamora-Camacho FJ, Moreno-Rueda G (2014) The lizard Psammodromus algirus (Squamata Lacertidae) is darker at high altitudes. Biological Journal of the Linnean Society 112: 132-41. https://doi.org/10.1111/bij.12250

Saikia U, Sharma DK, Sharma RM (2007) Checklist of the Reptilian fauna of Himachal Pradesh, India. Reptile Rap 8: 6-9. https://www.zoosprint. zooreach.org/ZoosPrintNewsLetter/ReptileRap\%208\%20Dec07.pdf

Sinervo B, Miles DB, Wu Y, Mendez-de La Cruz F, Kirchhof S, Qi Y (2018) Climate change, thermal niches, extinction risk and maternal-effect rescue of toad-headed lizards, Phrynocephalus, in thermal extremes of the Arabian Peninsula to the Qinghai-Tibetan Plateau. Integrative Zoology 13: 450-470. https://doi.org/10.1111/17494877.12315 
Valladares P (2004) Nueva especie de lagarto del género Liolaemus (Reptilia: Liolaemidae) del norte de Chile, previamente confundido con Liolaemus (= Phrynosaura) reichei. Cuadernos de Herpetología 18: 41-51.

Verrastro L, Veronese L, Bujes C, Dias-Filho MM (2003) A new species of Liolaemus from Southern Brazil (Iguania: Tropiduridae). Herpetologica 59(1): 105-118. https://doi.org/10.1655/0018-0831(2003)0 59[0105:ANSOLF]2.0.CO;2

Villegas-Paredes L, Huamaní-Valderrama L, Luque-Fernández C, Gutiérrez RC, Quiróz AJ, Abdala CS (2020) Una nueva especie de $\mathrm{Li}$ olaemus (Iguania: Liolaemidae) perteneciente al grupo L. montanus en las lomas costeras del sur de Perú. Revista de Biología Tropical 68(1): 69-86. https://doi.org/10.15517/rbt.v68i1.34861

Whitaker R, Captain A (2004) Snakes of India, the Field Guide. Draco Books, Chennai, 481 pp.
Wilson RJ, Gutiérrez D, Gutiérrez J, Martínez D, Agudo R, Monserrat VJ (2005) Changes to the elevational limits and extent of species ranges associated with climate change. Ecology Letters 8: 1138-1146. https://doi.org/10.1111/j.1461-0248.2005.00824.x

Yang W, Qi Y, Fu J (2014) Exploring the genetic basis of adaptation to high elevations in reptiles: a comparative transcriptome analysis of two toad-headed agamas (genus Phrynocephalus). PLoS ONE 9: e112218. https://doi.org/10.1371/journal.pone.0112218

Yang Y, Wang L, Han J, Tang X, Ma M, Wang K, Zhang X, Ren Q, Chen Q, Qiu Q (2015) Comparative transcriptomic analysis revealed adaptation mechanism of Phrynocephalus erythrurus, the highest altitude Lizard living in the Qinghai-Tibet Plateau. BMC Evolutionary Biology 15: 101. https://doi.org/10.1186/s12862-015-0371-8

Zhao EM, Zhao KT, Zhou KY (1999) Fauna Sinica: Reptilia (Squamata, Lacertilia) (Vol. 2). Science Press. 